\title{
DIALEKTIKA RADIKALISME DAN ANTI RADIKALISME DI PESANTREN
}

\author{
Thohir Yuli Kusmanto, Moh. Fauzi, M. Mukhsin Jamil \\ Universitas Islam Negeri (UIN) Walisongo Semarang \\ e-mail: thohiryuli@yahoo.co.id
}

\begin{abstract}
Any effort opoosing toward any form of radicalism is a part of the reactions to antiradicalism. The spirit of anti-radicalism emerged as part of the people's resistance. Radicalism and anti-radicalism was dialectically interrelated. Although both are paradoxical, but always be united. Dialectic of radicalism and anti-radicalism interesting is once it was observed in boarding school life. The phenomena of Islamic radicalism is often associated with Islamic boarding schools in Indonesia. Some communities understood that the growing radicalism came from Islamic boarding schools. This view was based on the the many actors of violent Islamic radicalism were the alumni of boarding school. The reality may be true in certain cases, but they may not be generalized. This study explored the data on the perspective of Islamic boarding schools on the discourse and praxis of radicalism and anti radicalism and resistance patterns. The research results showed that the community of Islamic boarding schools rejected, oppossed and actively built the spirit of anti radicalism that was implemented in several patterns. The findings of these research was a synthesis of the thesis which had become the public discourse about radicalism and Islamic boarding school.

Upaya menentang segala bentuk radikalisme merupakan bagian dari reaksi anti radikalisme. Semangat anti radikalisme muncul sebagai bagian dari resistensi masyarakat. Radikalisme dan anti radikalisme saling berkaitan secara dialektis. Meskipun keduanya merupakan sesuatu yang paradoks, namun selalu menyatu. Dialektika radikalisme dan anti radikalisme menarik ketika dilihat dalam kehidupan pesantren. Fenomenaradikalisme Islam seringkali dihubungkan dengan masyarakat pesantren di Indonesia. Beberapa kelompok masyarakat memahami radikalisme tumbuh dari pesantren. Pandangan tersebut didasari oleh banyaknya pelaku radikalisme Islam dalam bentuk kekerasan alumni pesantren. Realitas tersebut bisa jadi benar dalam kasus tertentu, tetapi tidak bisa digeneralisasi. Penelitian ini berupaya menggali data pandangan pesantren tentang wacana dan praksis radikalisme dan anti radikalisme serta pola resistensinya. Hasil penelitian menunjukkan bahwa masyarakat pesantren menolak, menentang dan aktif membangun spirit anti radikalisme yang diwujudkan dalam beberapa pola. Temuan penelitian tersebut merupakan sintesis dari tesis yang selama ini menjadi wacana masyarakat tentang radikalisme dan pesantren.
\end{abstract}

Keywords: dialektika, radikalisme, anti radikalisme, pesantren

Walisongo, Volume 23, Nomor 1, Mei 2015 


\section{A. Pendahuluan}

Radikalisme atas nama agama, yang tidak jarang menggunakan instrumen kekerasan menjadi fenomena menonjol dan menarik perhatian kembali dunia internasional saat ini. Berkembangnya wacana tentang gerakan Islamic State of Iraq and Syiria (ISIS) menjadi topik perbincangan dan perhatian serius berbagai kalangan. Mereka berasal baik dari level lokal, nasional maupun internasional. Pemerintah di berbagai negara dan kelompok-kelompok masyarakat merespon ISIS dalam beragam pandangan. Umumnya menentang keberadaannya. Hal tersebut disebabkan oleh sifat radikalisme ISIS yang lebih terbuka, massif, dan terorganisir. Mereka memiliki kekuatan militer dan politik yang lebih baik dari bentuk-bentuk gerakan Islam radikal sebelumnya. Pemerintah Indonesia ikut merespon secara serius. Pada akhir periode masa kepemimpinan Susilo Bambang Yudhoyono, pemerintah Indonesia memberi peringatan secara jelas agar Indonesia tidak tidur menghadapi ISIS, karena telah berkembang meluas di berbagai negara.

Masyarakat sipil ikut serta merespon fenomena ISIS tersebut. Mereka adalah kalangan ulama atau intelektual Islam, baik secara kelembagaan maupun personal. Masyarakat sipil Indonesia melihat perilaku ISIS jauh menyimpang dari kaidah keislaman. Ketua MUI, Din Syamsuddin berpendapat bahwa ISIS lebih berbahaya dibandingkan dengan kelompok-kelompok radikal yang pernah ada. Sedangkan Ketua Umum PBNU, Said Aqil Siraj juga memberikan pandangan bahwa dawlah islāmiyyah dan khiläfah yang mereka proklamirkan itu omong kosong. ISIS melakukan kebobrokan dengan cara merampok bankbank pemerintah. Mereka berhasil mengumpulkan dana 2 milliar dolar.

Radikalisme merupakan fakta sosial yang spektrumnya merentang dari lingkungan makro (global), lingkungan messo (nasional) maupun lingkungan mikro (lokal). Kajian mengenai radikalisme lebih banyak memberi perhatian kepada proses radikalisasi dan akibat-akibat radikalisme. Dalam pendekatan tersebut, berupaya mengetahui faktor-faktor yang menyebabkan individu atau kelompok bertindak radikal. Mereka memandang bahwa keyakinan, latar belakang pendidikan, kondisi sosial dan ekonomi menjadi faktor-faktor yang membentuk proses radikalisasi. Selain itu tindakan radikal, seringkali dipandang sebagai pilihan rasional bagi sekelompok orang. Tindakan radikal 
melibatkan mobilisasi sumber daya dan kesempatan politik yang dibingkai dengan kerangka tertentu, misalnya agama. ${ }^{1}$

Kajian atas radikalisme memiliki kecenderungan memberi bobot lebih terhadap hubungan antara radikalisme dengan agama. Tindakan radikal selalu dicarikan akarnya dalam dimensi agama. Radikalisme di kalangan Islam misalkan selalu dikaitkan dengan ideologi jihadisme. ${ }^{2}$ Radikalisme dilihat dalam dimensi konstitutif pada aspek yang paling sublim dalam kehidupan manusia sebagai keyakinan agama. Pandangan tersebut menyebabkan kesulitan untuk mengatasinya. Keyakinan merupakan dimensi kehidupan manusia yang sangat sulit diintervensi.

Radikalisme dalam dimensi sosial, hanya bisa direduksi dan di-counter dengan gejala sosial lain yaitu gerakan anti radikalisme. Respons para tokoh agama di atas merupakan ekpresi kontra radikalisme. Perhatian kalangan luas baik pemerintah maupun masyarakat mengenai radikalisme, mencerminkan bahwa radikalisme merupakan masalah yang serius dan melekat padanya kontra radikalisme.

Dalam konteks aktor radikalisme, wacana yang berkembang dipahami sebagai kelompok orang yang kebanyakan terdidik dari pendidikan pesantren. Akibatnya tumbuh dalam pemahaman publik bahwa pesantren merupakan tempat pendidikan bagi calon teroris. Fakta ke-Indonesia-an pendidikan pesantren tidak mengajarkan tentang radikalisme. Isu radikalisme yang mengaitkannya dengan pesantren telah membuat opini publik terhadap pesantren menjadi buruk. Keberadaan kurikulum pengajaran seringkali menjadi faktor utama keterlibatan pesantren dalam radikalisme. ${ }^{3}$

Tuduhan yang menyatakan keterlibatan pesantren sebagai jaringan Islam radikal tidak hanya pada ranah wacana di media. Negara pun merespon situasi tersebut dalam bentuk perlu adanya proses pengawasan yang ketat terhadap keberadaan pesantren di masyarakat. Hal ini mengacu pada pernyataan Pemerintah RI melalui Wakil Presiden RI Muhammad Yusuf Kalla -pada masa

\footnotetext{
${ }^{1}$ Baca: Quintan Wiktorowicz, Gerakan Sosial Islam: Teori, Pendekatan dan Studi Kasus, (Jakarta: Gading Publishing, 2012).

2Baca: Kasjim Salenda, Terorisme dan Jihad dalam Perspektif Hukum Islam, (Jakarta: Badan Litbang dan Diklat, Departemen Agama RI, 2009).

${ }^{3}$ Baca: Nuhrison M. Nuh (ed.), Peranan Pesantren dalam Mengembangkan Budaya Damai, (Jakarta: Badan Litbang dan Diklat Kementerian Agama, 2010), h. 3.
} 
Pemerintahan Presiden Susilo Bambang Yudhoyono- yang akan mengawasi dengan ketat, aktivitas pesantren yang tersebar di tanah air. Menurutnya beberapa aksi teror di antaranya peristiwa bom Bali tidak menutup kemungkinan, para pelakunya santri dari pondok pesantren yang tersebar di tanah air. ${ }^{4}$

Wacana mengenai relasi pesantren dengan radikalisme, merujuk pada dua kemungkinan. Pertama, pesantren-pesantren tersebut hadir dalam masyarakat mengambil pola pendidikan impor dari luar negeri (negara yang menjadi basis Islam radikal-red.). Kedua, cara pandang keislamannya tekstual skripturalistik, akibatnya pemahaman konteks atas suatu teks keagamaan (al-Qur'an dan Hadits) kurang. Fenomena tersebut dipengaruhi oleh pemikir Timur Tengah seperti Sayyid Qutb, Hasan al-Banna dan lain-lainnya. ${ }^{5}$

Namun fakta tidak sepenuhnya benar bahwa akar dan aktor dari munculnya radikalisme adalah pesantren. Faktor pemberitaan oleh media massa menjadi kunci dari wacana tersebut. Tidak sedikit pesantren yang melakukan upaya untuk men-counter gerakan radikalisme. Upaya tersebut merupakan bagian dari resistensi masyarakat lokal (mikro) atas wacana yang berkembang pada aras nasional (meso) dan global (makro).

Berdasarkan latar belakang tersebut maka peneliti tertarik untuk meneliti tentang radikalisme dan kontra radikalisme di lembaga pesantren. Penelitian ini diharapkan bisa mengungkapkan radikalisme dan kontra radikalisme sebagai fenomensa sosial. Pesantren yang menjadi perhatian adalah pesantren di Surakarta. Pertimbangan utama memilih Surakarta adalah wacana dan praksis tentang gerakan radikalisme Islam sangat kuat ditujukan pada wilayah ini. Bahkan beberapa pelaku teror banyak yang ditangkap dan terbunuh di sini. Ada pesantren yang diindikasikan sebagai sumber munculnya aktor teror berada di kota ini. Begitu pula banyak organisasi massa keislaman tumbuh dan berkembang dengan menekankan aksi radikal. Gerakan anti radikalisme pun tumbuh, sebagai tandingannya. Ada pesantren yang terlibat aktif dalam membangun wacana dan praksis untuk melawan radikalisme (kontra radikalisme).

Masalah utama yang menjadi perhatian peneliti yaitu: dialektika pada aras diskursus dan praksis radikalisme dan kontra radikalisme di pesantren, pengembangan kurikulum dan tata nilai tentang radikalisme dan kontra radikal-

\footnotetext{
${ }^{4}$ Baca: Kosim, "Mohammad, Pesantren dan Wacana Radikalisme", Jurnal Karsa, Vol. IX No. 1 April 2006. h. 843.

${ }^{5}$ Nuhrison M. Nuh, (ed.), Peranan Pesantren dalam Mengembangkan Budaya Damai, h. 3.
} 
isme di pesantren, dan latar belakang dan pola resistensi pesantren terhadap gerakan radikalisme. Peneliti berharap mampu mendeskripsikan diskurusus radikalisme dan kontra radikalisme sebagai suatu dialektika, menggambarkan pengembangan kurikulum dan tata nilai tentang radikalisme dan kontra radikalisme di pesantren, dan menjelaskan latar belakang dan pola resistensi pesantren terhadap redikalisme.

Penelitian ini menggunakan pendekatan kualitatif, dengan jenis deskriptif studi kasus. Aspek utama dari penelitian ini adalah kehidupan masyarakat pesantren, sumber data utamanya meliputi: kiai, ustadz, pengurus pesantren, santri dan masyarakat sekitar pesantren. Lokus penelitian ini adalah Pondok Pesantren Modern Islam Assalaam dan Pondok Pesantren Al-Muayyad di Surakarta. Kedua pesantren merepresentasi modernitas dan tradisionalis. Teknik pengumpulan datanya meliputi; observasi, wawancara mendalam, dan dokumentasi (baik tertulis maupun tidak tertulis), dengan tekni analisa data bersifat interaktif.

\section{B. Dialektika Radikalisme dan Anti Radikalisme}

Diskursus tentang redikalisme dan kontra radikalisme dalam kehidupan pesantren merupakan bagian dari dialektika sosial. Dalam konteks dialektika dikursus merupakan satu sisi yang akan berhadapan dengan sisi yang lain yaitu praksis. Diskursus lebih banyak berkembang pada ruang abstrak dan makro serta tekstualis. Sedangkan praksis lebih empiris dan kontekstual sehingga lebih dengan kehidupan sehari-hari.

Diskursus dan praksis merupakan dua hal yang menyatu sebagai dialektika. Keduanya sangat membantu untuk memahami gejala sosial radikalisme dan kontra radikalisme. Merujuk pada Berger dan Luckmann ${ }^{6}$ menjelaskan bahwa dalam dialektika masyarakat diskursus dan praksis merupakan realitas pengetahuan. Sebagai pengetahuan keduanya merupakan pengetahuan yang terlepas dari persoalan, kesahihan atau ketidaksahihan yang paling dasar (berdasarkan kriteria apapun) dari pengetahuan itu. Sebagai pengetahuan manusia keduanya dikembangkan, dialihkan dan dipelihara dalam berbagai kondisi sosial, proses-proses tersebut pada akhirnya membentuk kenyataan yang dianggap wajar oleh orang awam. Sebagai hal yang dianggap wajar, ia menjadi hal yang biasa dalam kehidupan sehari-hari suatu masyarakat.

${ }^{6}$ Berger, Peter L., dan Thomas Luckmann. Tafsir Sosial Atas Kenyataan, terj. Hasan Basari. (Jakarta: LP3ES, 1990), h. 4.

Walisongo, Volume 23, Nomor 1, Mei 2015 
Upaya memahami radikalisme dan anti radikalisme di dunia pesantren dengan pendekatan logika dialektik, maka tidak bisa keluar dari kerangka pemikiran dialektika Marxisme. Logika dialektika Marxisme merupakan cara berpikir yang melihat inti segala sesuatu adalah kontradiksi, baik di dalam alam maupun di dalam kehidupan manusia. Oleh karena itu kontradiksi adalah sentral dari segala sesuatu yang ada di alam. ${ }^{7}$ Proposisi tersebut sangat relevan untuk menjelaskan dinamika radikalisme dan anti radikalisme di pesantren. Wacana keduanya dalam ranah praksis menghadapkan dunia pesantren pada realitas kontradiktif, pada satu sisi publik memahami radikalisme Islam tumbuh dari pesantren, sisi yang lain anti radikalisme pun sangat kuat datang dari pesantren yang mewujud dalam berbagai bentuk aksi dan pemikiran.

Wacana dialektika Marx tidak bisa dilepaskan dari pemikiran Hegel. Berangkat dari pemikiran Hegel, Marx memahami dunia sosial. Pemikiran dialektis Marx sejalan dengan Engels. Dialektika menurut Engels menegaskan pemikiran Hegel dalam Lauer memiliki beberapa kaidah tertentu yaitu: (1) Segala sesuatu yang ada, ditandai oleh kesatuan dan konflik dengan lawannya. Dalam istilah lain segala sesuatu yang ada, ditandai oleh adanya kontradiksi. Kontradiksi menjadi sifat dari alam maupun masyarakat. (2) Dalam kehidupan sosial, kontradiksi dapat dilihat dalam pertentangan antara kekuatan-kekuatan dan hubunganhubungan produksi dalam masyarakat kapitalis. Dalam situasi seperti itu, maka kontradiksi merupakan suatu kesatuan dan konflik antara kekuatan-kekuatan yang berlawanan. Keduanya tidak terelakkan dipersatukan di dalam masyarakat yang sama, tetapi saling konflik satu sama lain. (3) Kontradiksi menjadi mekanisme yang menggerakkan perubahan, karena kontradiksi tidak dapat dipertahankan untuk jangka waktu yang tak terbatas. ${ }^{8}$

Dalam pendekatan dialektis kehidupan sosial tidak ada aspek parsial dan tidak ada fenomena terpencil. Kehidupan sosial selalu terkait dengan keseluruhan historis, dengan struktur sosial yang dibayangkan sebagai entitas global. ${ }^{9}$ Dialektika menolak paham yang melihat kehidupan sosial pada aspek spesifik, khususnya sistem ekonomi, di luar konteksnya yang lebih luas. Perhatian utamanya antar hubungan berbagai level realitas sosial yang paling

\footnotetext{
${ }^{7}$ Lauer, Robert H., Perspektif tentang Perubahan Sosial, ed. II, terj. Alimandan, (Jakarta: Bina Aksara, 1989), h. 90.

${ }^{8}$ Lauer, Robert H., Perspektiftentang Perubahan Sosial, h. 90-91.

${ }^{9}$ George Ritzer, Teori Sosiologi, terj. Saud Pasaribu, Rh. Widodo, dan Eka Adhinugraha, (Yogyakarta: Pustaka Pelajar, 2012), h. 487.
} 
penting. Kesadaran individual, superstruktur budaya, dan struktur ekonomi. Secara metodologis memahami realitas sosial sebagai satu komponen kehidupan sosial, yang tidak dapat dipelajari secara terpisah dari komponen-komponen lainnya. ${ }^{10}$ Dialektika radikalisme dan antiradikalisme merupakan realias kehidupan sosial yang kompleks. Keduanya hadir dalam ruang sosial sebagai saling kait mengkait antar komponen masyarakat.

Radikalisme dan kontra radikalisme agama merupakan bentuk baru gerakan sosial keagamaan. Sebagai gerakan sosial, maka merupakan dinamika keagamaan masyarakat yang terorganisir. Pengorganisasiannya untuk mencapai tujuan kehidupan yang relevan dengan nilai-nilai agama, atas dasar pemahaman dan pemaknaan ajaran-ajaran agama yang bersifat transenden. Keragaman agama dan aliran keagamaan dalam masyarakat menyebabkan beragam pula bentuk, strategi dan orientasi gerakan. Akibatnya sering terjadi benturan dan atau menyatu di antara persamaan dan atau perbedaan yang melekat dalam dirinya. Klaim kebenaran (truth claim) sangat menentukan dinamika gerakan sosial keagamaan. Radikalisme dan anti radikalisme merupakan bentuk aktual dari klaim kebenaran. Oleh karena masing-masing memiliki perspektif kebenarannya sendiri-sendiri.

Modernisasi merupakan tantangan dan peluang serta menjadi isu utama dari gerakan sosial keagamaan. Pada satu sisi modernisasi dipahami sebagai faktor yang menyebabkan masyarakat keluar dari pemahaman dan pengamalan ajaran-ajaran agama, sehingga harus dihindari dan disingkirkan. Namun, sisi yang lain menerimanya secara selektif dan bahkan ada yang menerimanya sepenuhnya karena menjadi sarana menuju peradaban manusia yang lebih baik. Ajaran agama harus menyesuaikan dengan konteks perkembangan tersebut. Pengkajian ulang atas ajaran-ajaran agama mesti dilakukan, agar tidak terjadi benturan atau ketimpangan dengan modernisasi.

Dalam modernitas, agama mendapatkan ruang terbuka bagi terjadinya radikalisme dan anti radikalisme. Sebagai gambaran dijelaskan oleh Nottingham ${ }^{11}$ bahwa agama merupakan sarana kebudayaan bagi manusia di dalam menyesuaikan diri dengan pengalaman-pengalamannya dalam keseluruhan lingkungan hidupnya. Baik lingkungan di dalam dirinya sendiri, kelompok, alam maupun lingkungan lain yang dirasakan sebagai sesuatu yang transendental (tidak terjangkau penalaran manusia).

\footnotetext{
${ }^{10}$ George Ritzer, Teori Sosiologi, h. 487.

11Elisabeth K. Nottingham, Agama dan Masyarakat, (Jakarta: Rajawali Pers, 1997), h. 9.
} 
Ada beragam makna dalam semangat radikal di kalangan masyarakat beragama (Islam). Jihad merupakan bagian dari pemaknaan tersebut. Meskipun banyak kalangan yang menyatakan bahwa pemaknaan tersebut sebagai sebuah kesalahan. Namun faktanya, produksi dan reproduksi atas konsep dan wacana tersebut merebak di masyarakat. Semangat jihad hadir tidak di ruang hampa, banyak faktor yang mempengaruhinya. Di antaranya; kemiskinan, kejenuhan di ranah sosial dan politik, fanatisme kelompok dan doktrin teologi, yang saling terkait satu dengan lainnya. Azyumardi Azra menjelaskan bahwa radikalisme berasal dari kata radikal, mengacu kepada keadaan, orang, atau gerakan tertentu yang menginginkan perubahan sosial dan politik secara cepat dan menyeluruh, dan tidak jarang dilakukan dengan menggunakan cara-cara tanpa kompromi dan bahkan kekerasan, bukan dengan cara-cara damai. ${ }^{12}$

Radikal berbasis agama menurut Scott Appleby sebagai ekspresi atas 'Kemarahan Sakral' melawan diskriminasi rasial, etnis dan agama; ketidakadilan kebijakan ekonomi, korupsi dan hipokritas dalam pemerintah; kebijakan negara atau swasta yang timpang atau menindas kelompok-kelompok masyarakat kecil dan lemah, kekerasan sistematis dan keamanan. Oleh karena itu upaya meredam radikalisme (anti radikalisme) agama harus mengacu pada problem-problem sosial politik, ekonomi dan budaya yang melatarbelakanginya. Pendekatan yang tidak menyentuh akar persoalan, menjadikannya berlarut-larut dan tanpa ujung. Bahkan akan mereproduksi terus-menerus dalam bentuk yang lebih variatif. Apalagi jika cara-cara menyelesaikannya dengan kekerasan.

Radikalisme keagamaan sebagian yang lain, dipahami sebagai cara memperjuangkan keyakinan keagamaan yang dianutnya. Mereka memperjuangkannya tanpa kompromi dan bila perlu dengan cara anarkisme dan kekerasan. Faktorfaktor yang memunculkan radikalisme dalam bidang agama, antara lain, (1) pemahaman yang keliru atau sempit tentang ajaran agama yang dianutnya, (2) ketidakadilan sosial, (3) kemiskinan, (4) dendam politik dengan menjadikan ajaran agama sebagai satu motivasi untuk membenarkan tindakannya, dan (5) kesenjangan sosial atau iri hati atas keberhasilan orang lain. ${ }^{13}$

M. Dawam Raharjo mengemukakan 4 hipotesis yang melatar belakangi berkembangnya Islam radikal di Indonesia, yaitu: (1) Pengaruh gerakan-gerakan

\footnotetext{
${ }^{12}$ Nuhrison M. Nuh (ed.), Peranan Pesantren dalam Mengembangkan Budaya Damai, h. 2.

${ }^{13}$ Nuhrison M. Nuh (ed.), Peranan Pesantren dalam Mengembangkan Budaya Damai, h. 2.
} 
Islam transnasional seperti Ikhwan al-Muslimin, Hizbut Tahrir, Wahabisme Saudi Arabia, Islam Taliban, dan Al-Qaeda, yang semuanya mencita-citakan tegaknya syariat Islam di semua bidang kehidupan. (2) Pengaruh euphoria demokratisasi di Indonesia, yang dimaknai sebagai peluang bagi munculnya gerakan-gerakan Islam radikal yang pada masa Orde Baru dibungkam dan dipaksa tiarap oleh pemerintahan yang otoriter sekuler. (3) Gagalnya penegakan negara hukum demokratis, sehingga menimbulkan kembali inspirasi untuk menegakkan syariat Islam, sesuatu yang pada dasarnya bertolak belakang dengan sistem hukum demokratis yang sekuler. (4) Gagalnya gerakan dakwah yang rahmatan li ''ālamin, yang toleran terhadap keyakinan beragama yang berbeda-beda dan bersifat inklusif. Berkembangnya gerakan dakwah yang eksklusif dan intoleransi terhadap keragaman. ${ }^{14}$

Usaha mengatasi perkembangan dan perluasan gerakan radikal di masyarakat, harus dilakukan secara kolektif, atas dasar kesadaran dan keterlibatan penuh elemen masyarakat. Ada dua strategi yang bisa digunakan; kontra radikalisme dan deradikalisasi. Kontra radikalisme merupakan upaya yang bersifat preventif (pencegahan), yang diarahkan pada semua elemen masyarakat. Kontra radikalisme dilakukan dengan kampanye pada semua elemen masyarakat, untuk membangun kesadaran atau pemahaman bahwa radikalisme dalam bentuk teror adalah bentuk kekerasan. Ia tidak ada terkait dengan ajaran keagamaan, harus dilawan secara bersama-sama. ${ }^{15}$ Gerakan kontra radikalisme telah menjadi bagian dari praksis dalam kehidupan pesantren sejak mereka membangun institusi. Terutama pesantren yang dibangun di atas pondasi moderatisme, sehingga spirit pembelajaran dan kehidupan pesantren diarahkan untuk menghindari, mencegah dan melawan segala bentuk radikalisme atas nama agama. Fenomena ini bisa ditemukan pada pesantren yang peneliti teliti.

Deradikalisasi merupakan strategi dalam mengatasi masalah radikalismeterorisme, yang bersifat recovery (perbaikan atau penyembuhan) kepada aktor dan pihak lain yang terlibat dalam gerakan ini. Mereka para pelaku teror seringkali telah terindoktrinasi atau mengalami ideologisasi atas gerakan radikalisme. Adanya proses ideologisasi tersebut menyebabkan mereka menjadi orang yang menderita sakit "radikalisme". Deradikalisasi merupakan upaya

\footnotetext{
${ }^{14}$ Baca: M. Dawam Raharjo, "Fanatisme dan Toleransi”, pengantar dalam Irwan Masduqi, Berislam Secara Toleran, (Bandung: Mizan, 2011), h. xxvii.

${ }^{15}$ Agus SB, pengantar dalam Ikhwanul Kiram Mashuri, ISIS Jihad atau Petualangan, (Jakarta: Republika Penerbit, 2014), h. xv.
} 
penyembuhan atau mengurangi tingkat keradikalannya (less radical). ${ }^{16} \mathrm{Ke}-$ terlibatan pesantren yang peneliti teliti dalam usaha deradikalisasi, bergerak dalam ruang wacana dan praksis. Pada ranah wacana, mereka memainkan peran dalam bentuk kampanye, kajian-kajian, dan membangun solidaritas di antara pesantren dan lembaga pemerintah. Sebagai praksis pesantren mengintegrasikan dalam kurikulum dan nilai-nilai atau aturan dalam dinamika kehidupan pesantren.

Deradikalisasi telah menjadi bagian dari masyarakat global. Perserikatan Bangsa-Bangsa pun ikut menjadi bagiannya, dengan membentuk sayap kelembagaan yang mengurusi persoalan kontra terorisme. Divisi kontra-terorisme PBB mengkonstruksi sebuah konsep deradikalisme, "De-radicalization, therefore, is the process of abandoning an extremist worldview and concluding that it is not acceptable to use violence to effect social change." 17

Deradikalisasi bisa dilakukan dengan berbagai cara. Pendidikan perdamaian merupakan salah satu cara yang efektif. Pendidikan ini berproses dalam pembelajaran yang mengajarkan realitas keragaman (pluralisme) agama, ras, suku, budaya, dan bahasa yang harus dikelola dan dihormati. Peserta didik akan dapat menjauhkan diri dari sikap dan tindakan-tindakan ekstrem dan radikal, terutama yang mengatasnamakan agama. Pendidikan perdamaian (peace education) dapat menjadi proses deradikalisasi umat beragama. ${ }^{18}$

\section{Kurikulum dan Tata Nilai tentang Radikalisme dan Anti Radikalisme di Pesantren}

Dialektika radikalisme dan anti radikalisme dapat dilihat pada aras wacana ${ }^{19}$ dan praksis. Relasi keduanya bisa bersifat dialektis karena bisa jadi

\footnotetext{
${ }^{16}$ Agus SB, pengantar dalam Ikhwanul Kiram Mashuri, ISIS: Jihad atau Petualangan, h. xv-xvi.

${ }^{17}$ United Nations, “Counter-Terrorism Implementation Task Force, 2008: h. 5.

${ }^{18}$ Imam Machali, “Peace Education dan Deradikalisasi Agama”, Jurnal Pendidikan Islam, Vol. II, No. 1, Juni 2013/1434 H, h. 50.

${ }^{19}$ Menurut Foucault bahwa wacana mudah dipahami dan dijelaskan berdasarkan bekerjanya suatu pengetahuan sebagai kumpulan dari suatu pernyataan (statemen). Statemen-statemen yang terlontar dan mempengaruhi masyarakat, kemudian menjadi sebuah pengetahuan yang tersebar dan membuat orang lain mengikutinya. Wacana merupakan penjelasan, pendefinisian, pengklasifikasian dan pemikiran tentang orang, pengetahuan dan sistem abstrak pemikiran. Keberadaannya tidak bisa lepas dari kekuasaan dan pengetahuan. Edward Said dalam Turner menjelaskan peran wacana sebagai sebagai sesuatu yang melahirkan serangkaian kontras (perbedaan-perbedaan) yang membedakan realitas yang ada di sekeliling suatu masyarakat dengan kebudayaan lainnya. Baca: Turner, Bryan S., Relasi Agama dan Teori Sosial Kontemporer, terj. Inyiak Ridwan Muzir, (Yogyakarta: IRCiSoD, 2012), h. 19.
} 
terjadi paradoks antara wacana dan prakis atas keduanya. Dalam penelitian ini peneliti menemukan bahwa wacana tentang radikalisme dan anti radikalisme di kalangan pesantren cukup beragam. Faktor pemahaman dan sumber pengetahuan tentang radikalisme dan anti radikalisme berpengaruh sangat kuat. Upaya menggali wacana tentang radikalisme dan anti radikalisme di kalangan pesantren pada wilayah pandangan dan praktik serta proses pembelajaran atas keduanya dalam kehidupan sehari-hari.20

Dalam wacana dan praksisnya, kalangan pesantren di Surakarta pada umumnya menentang adanya radikalisme. Meskipun ada pesantren yang dilabeli sebagai pesantren yang melahirkan kader atau mantan santri yang menjadi pelaku tindak radikalisme. Wacana dan praksis tentang radikalisme dan anti radikalisme terintegrasi dalam kurikulum pembelajaran dan tata nilai yang mengatur pola hubungan antar aktor di pesantren. Dalam penelitian ini peneliti menelisik wacana tentang radikalisme dan anti radikalisme pada pesantren yang tidak termasuk dilabeli sebagai basis gerakan radikal. Adapun pesantren tersebut adalah Pondok Pesantren Al-Mu'ayyad dan Pondok Pesantren Modern Islam Assalaam.

Dalam pandangan Pesantren Al-Muayyad, ada 2 (dua) tipologi pemahaman keagamaan terhadap Islam yang melahirkan dikotomi Islam inklusif (yang menentang radikalisme) dan Islam eksklusif (yang melegalkan radikalisme) merupakan sunnatullāh (hukum alam). Dalam hal ini, manusia -sebagai khalīfatullāh fi 'l-arḍ- diberi kebebasan untuk menyikapi kedua tipologi pemikiran sesuai pandangannya. ${ }^{21}$

Adanya gerakan radikal sebagai sunnatullāh, didasarkan fakta sejarah dalam Islam yakni lahirnya kelompok-kelompok yang memisahkan diri dari kelompok mainstream yang dalam praktek politiknya melegalkan kekerasan, seperti kelompok Khawarij, Syi'ah, dan lainnya. Adanya fakta gerakan yang

\footnotetext{
${ }^{20}$ Interrelasi antara praktik dan proses pembelajaran yang akhirnya merumuskan teori biasa dikenal dengan istilah praksis. Ife dan Tesoriero menjelaskan tentang praksis sebagai keterlibatan seseorang dalam satu putaran konstan dari pelaksanaan (praktik), pembelajaran, dan refleksi kritis, sehingga salah satu dari ketiga hal tersebut bisa memberikan informasi pada yang lain dan ketiganya secara efektif menyatu. Oleh karenanya praksis bukanlah suatu tindakan yang sederhana, ia mencakup pemahaman, pembelajaran, dan pembangunan teori. Baca: Ife, Jim dan Frank Tesoriero, Community Development; Alternatif Pengembangan Masyarakat di Era Globalisasi, terj. Sastrawan Manulang, dkk., (Yogyakarta: Pustaka Pelajar, 2008.), h. 554.

21Wawancara dengan Faishol Rozaq, Ketua Umum Pesantren Al-Muayyad, Senin, 20 Oktober 2014, jam 09.00-11.30.
} 
cenderung radikal ini oleh pimpinan Al-Muayyad disampaikan kepada santri sehingga mereka mengetahui sejarah dan bersikap bijaksana.

Menurut Pesantren Al-Muayyad, munculnya gerakan radikal tersebut karena berbagai faktor. Dalam lingkup yang terkecil dikarenakan tidak hadirnya keluarga. Seperti juga anak-anak yang terjerumus dalam geng motor, disebabkan tidak hadirnya keluarga dalam kehidupan mereka. Faishol, Ketua Umum Al-Muayyad, mengisahkan anak temannya yang dididik di salah satu pesantren di Sukoharjo yang diklaim sebagai pemasok teroris. Meskipun sebenarnya dalam kehidupan rumah tangga temannya tata cara berpakaiannya mirip dengan tradisi di pesantren Sukoharjo tersebut, namun temannya kaget dengan model pendidikan di pesantren yang mengajarkan kekerasan dalam menyebarkan dakwah Islam. Keluarga yang memasukkan anaknya ke pesantren yang mengajarkan kekerasan berarti menyetujuinya. Hal ini menunjukkan tradisi kekerasan berawal dari dukungan keluarga. Sedangkan dalam lingkup yang luas, penyebab lahirnya gerakan radikal adalah karena negara absen menjalankan peran dan fungsinya dengan baik. Contoh kasus pesantren di Sukoharjo. Seandainya negara menjalankan peran dan fungsinya dengan baik semuanya akan beres. ${ }^{22}$

Faktor penyebab lainnya adalah aspek kurikulum yang digunakan pedoman proses belajar mengajar di pesantren. Kasus pesantren di Sukoharjo yang meng-absah-kan radikalisme dikarenakan kurikulum yang digunakan adalah kitab dan buku yang mengajarkan kekerasan. Dalam menafsirkan ayat atau hadis tentang peperangan mereka selalu menggunakan kata "bunuh" dan "bunuh". Lahirnya pemahaman radikal di pesantren tersebut sebenarnya bisa dirunut dari sejarah masa lalu. Dahulu para guru yang mengajarkan kepada generasi saat ini memang sudah berpaham garis keras. Sebenarnya dalam kitab tafsir itu memang ada yang mengajarkan kekerasan. Mereka memilih dan mengembangkan tafsir yang mengajarkan kekerasan. Kemudian mereka mewariskan kepada santri-santrinya. Kondisi ini membenarkan pernyataan bahwa lahirnya gerakan radikal sedikit banyak dipengaruhi pendidikan di pesantren. ${ }^{23}$

Langkah negara dengan melakukan penangkapan teoris yang diduga produk pesantren tersebut belumlah efektif. Al-Muayyad hanya melihat negara

22Wawancara dengan Faishol Rozaq, 20 Oktober 2014, jam 09.00-11.30.

23Wawancara dengan Faishol Rozaq, 20 Oktober 2014, jam 09.00-11.30. 
mempunyai kegiatan penangkapan saja, dan belum mampu menyumbat sumber utamanya. Peran strategis negara, dengan cara mengintervensi kurikulum yang diajarkan di pesantren. Meskipun Pemerintah sebenarnya telah melakukan sesuatu dengan menaruh orangnya yang bernama Amir dan Taufik namun langkah ini tidak efektif. Karena keduanya hanya secara fisik berada di pesantren tersebut, namun tidak bisa mengubah kurikulum pesantren. Sehingga ajaran radikal masih dipelajari dan bahkan didoktrinkan di pesantren tersebut. Negara tidak berani "memaksakan" kurikulum yang mengajarkan pemahaman yang inklusif di pesantren tersebut.

Kondisi berbeda terlihat pada zaman mendiang Presiden Soeharto yang selalu mengontrol dan memantau kurikulum pesantren di Sukoharjo, sehingga tidak muncul praktek radikal. Pada masa tersebut, negara berperan aktif dalam mengawasi kurikulum pendidikan pesantren. Pentingnya kurikulum mendorong Pondok Pesantren Al-Muayyad menggunakan kurikulum yang diakui Kemenag dan Kemendikbud. Seluruh Kitab-kitab yang digunakan di AlMuayyad sudah dimintakan persetujuan ke Kemenag Pusat. Pembelajaran di Al-Muayyad mengikuti kurikulum Negara (Kemenag dan Kemendiknas) paginya. Pembelajaran tambahan, mengkaji kitab-kitab yang sudah diuji oleh kemenag pada siang hari. Kitab yang dikaji diantaranya kitab mu'tabarah. Hal ini berbeda diterapkan pada pesantren di Sukoharjo yang mengabsahkan radikalisme. Pembelajarannya menggunakan kurikulum yang sama sekali tidak mengikuti kurikulum standar yang diberlakukan negara. ${ }^{24}$

Radikalisme di wilayah Solo memiliki akar sejarah pada 3 (tiga) Abdullah; Abdullah Thufail, Abdullah Sungkar, dan Abdullah Marzuki. Tiga Abdullah ini pada awalnya saling berteman namun pada akhirnya terjadi perbedaan dan perselisihan. Terkait tiga Abdullah yang secara umum mengajarkan Islam puritan telah dilakukan penelitian oleh Muthoharun Jinan. Hasil penelitiannya menunjukkan bahwa Abdullah Sungkar (pendiri gerakan Jama'ah Islamiyah) memilih jalur berseberangan dengan Negara, Abdullah Marzuki (pendiri Majelis Pengajian Islam) memilih jalur pendidikan pesantren dan tidak berpolitik dengan mendirikan PPMI Assalaam, dan Abdullah Thufail Saputro (pendiri gerakan Majelis Tafsir Al-Qur'an/MTA) memilih jalur akomodasi dan bekerjasama dengan Negara. ${ }^{25}$

\footnotetext{
${ }^{24}$ Wawancara dengan Faishol Rozaq, 20 Oktober 2014, jam 09.00-11.30.

${ }^{25}$ Baca: Muthoharun Jinan, "Melacak Akar Ideologi Puritanisme Islam: Survei Biografi atas "Tiga Abdullah", Walisongo Jurnal Penelitian Sosial Keagamaan, Vol. 22, No. 2, November 2014., h. 381-412.
} 
Pandangan yang berbeda dikemukakan oleh salah satu pimpinan Pondok Pesantren Modern Islam Assalaam tentang wacana radikalisme dan anti radikalisme. Respons civitas akademika Pondok Pesantren Modern Islam (PPMI) Assalaam tentang radikalisme dan anti radikalisme sangat beragam. Mereka memahami radikalisme sebagai realitas yang dominan pada ranah wacana (diskursus) dari pada sebagai praksis dalam masyarakat. Faktor yang menentukan penyebarluasan realitas radikalisme adalah pemberitaan melalui media massa yang sangat gencar dan kuat. ${ }^{26}$

Radikaliskalisme dalam pemahaman pengelola PPMI Assalaam realitas yang nyata dan tidak nyata. Oleh karena selama ini yang terjadi lebih banyak sebagai pemberitaan. Ia merupakan sesuatu yang jauh dari kehidupan nyata pesantren (khususnya PPMI Assalaam). Sebagai sesuatu yang nyata, radikalisme merupakan sikap atau tindakan yang muncul karena perbedaan dalam pemahaman dan keyakinan tentang sesuatu kebenaran. Mereka yang melakukan gerakan radikal merasa keyakinan atau pemahamannya benar, kemudian menginginkan agar kebenaran tersebut diterima, sampai harus menggunakan cara yang radikal. ${ }^{27}$

Faktor utama yang menentukan terjadinya radikalisme dalam masyarakat adalah upaya provokatif melalui berbagai media massa. Provokasi tersebut oleh beberapa kelompok umat Islam dilihat sebagai pencideraan terhadap kebenaran yang mereka yakini, sehingga meresponnya dalam bentuk perilaku atau tindakan radikal. Oleh karenanya radikalisme bisa dipahami sebagai bentuk perlawanan. ${ }^{28}$

PPMI Assalaam merupakan pondok pesantren yang menentang tindakan radikal agama dalam masyarakat. Namun demikian untuk merespon berkembangnya radikalisme dalam tataran diskursus, perlu sikap yang hati-hati. Ada kemungkinan diskursus tersebut merupakan bagian dari upaya memancing umat Islam untuk masuk secara nyata dalam wacana tersebut. Apalagi umat Islam dikenal dengan umat yang tenang dan sabar. ${ }^{29}$

26Wawancara dengan Komarudin, Kepala Humas PPMI Assalaam, 16 November 2014, jam 10.00.

27Wawancara dengan Komarudin, 16 November 2014, jam 10.00.

28Wawancara dengan Komarudin, 16 November 2014, jam 10.00.

${ }^{29}$ Wawancara dengan Komarudin, 16 November 2014, jam 10.00. 
Bentuk nyata dari upaya PPMI Assalaam dalam melawan radikalisme atau anti radikalisme yaitu menyusun suatu buku yang berjudul "Keassalaaman". Buku tersebut merupakan manifestasi pemikiran, tujuan, harapan, dan pola yang mengatur tingkah laku warga PPMI Assalaam yang di dalamnya mengajarkan dan menganjurkan untuk hidup selalu dalam perdamaian. Hal tersebut sebagai cerminan dari melekatnya nama "Assalaam" pada nama pondok pesantren.

Di antara nilai-nilai dasar atau prinsip dasar dari Keassalaaman yang menunjukkan anti radikalisme atau pro perdamaian yaitu prinsip rahmatan lil'alamin. Warga PPMI Assalaam mengacu pada ahli tafsir memaknainya sebagai kasih sayang Allah terhadap seluruh manusia baik mukmin maupun kafir dan juga bagi seluruh makhluk yang lain. Walaupun pun ada juga yang memaknai kasih sayang dari makna rahmat yang hanya diperuntukkan oleh Allah bagi orang yang beriman saja. ${ }^{30}$ Dalil naqli dari prinsip rahmatan li 'l'ālaminn dapat ditemukan dalam al-Qur'an, "Kami tidak mengutus engkau, wahai Muhammad, melainkan sebagai rahmat bagi seluruh manusia."31

Atas dasar prinsip rạ̣matan li 'l-'âlamīn di atas, PPMI Assalaam mengupayakan dakwah Islam yang damai dan santun lewat lembaga pendidikan dan pengajaran model pesantren kepada seluruh masyarakat. Prinsip raḥmatan li 'l'âlamīn dimaknai PPMI Assalaam sebagai ajaran Islam yang bisa memberikan pengayoman yang teduh bagi semua kalangan, bagi umat Islam dan bukan Islam. Sebagai catatan asal mereka tidak menggangu pelaksanaan ajaran dan proses dakwah Islam. ${ }^{32}$

Kontra radikalisme PPMI Assalaam dapat ditemukan dalam tata kelola pesantren yang meneguhkan sebagai pondok pesantren yang menjunjung tinggi perdamaian. Prinsip perdamaian dalam kehidupan bagi PPMI Assalaam, terkandung dalam makna yang melekat pada nama pondok pesantren "Assalaam". Assalaam bermakna damai: (1) Damai dengan sesama umat manusia. (2) Damai dengan pemerintah. (3) Damai dengan sesama umat manusia. (4) Damai dengan penganut agama lain. Implementasi konsep raḥmatan li 'l-âlamīn diwujudkan dalam model dan praktik pendidikan dan pengajaran yang berlangsung di kampus Assalaam selama 24 jam. ${ }^{33}$ Makna damai yang melekat dalam nama pondok

\footnotetext{
${ }^{30}$ Lihat dalam buku Keassalaaman, diterbitkan sendiri oleh PPMI Assalam, 2011, h. 19-20.

${ }^{31}$ QS. al-Anbiya' [21]: 107.

${ }^{32}$ Keassalaaman, h. 20.

${ }^{33}$ Keassalaaman, h. 20.
} 
pesantren tersebut, dalam praksisnya diwujudkan pada pola relasi dengan elemen-elemen keislaman, kemanusiaan, dan kemasyarakatan.

Di antara faktor penyebab radikalisme menurut PPMI Assalaam adalah kemajemukan Islam dalam masyarakat. PPMI Assalaam menyadari adanya kehidupan umat Islam yang majemuk. Realitas tersebut merupakan sesuatu yang tak bisa dihindari, akibat dari perkembangan pemikiran dan pemaknaan hukum Islam. Perkembangan ini telah menyebabkan adanya beragam aliran teologis dan mazhab kefiqihan. Menurut PPMI Assalaam, hal ini bisa dilihat dalam perkembangan organisasi dan partai politik Islam. Sebagai contoh; Muhammadiyah, Persis, NU, Dewan Dakwah, LDII, PKS, PKB, PBB,PPP dan lain-lainnya. ${ }^{34}$

Adanya kemajemukan organisasi dan partai politik tersebut memiliki potensi konflik. Dalam mensikapi realitas tersebut PPMI Assalaam meneguhkan diri berdiri di atas semua golongan. Warga PPMI Assalaam khususnya santri hanya berpegang teguh pada al-Qur'an dan As-Sunah, tidak ada upaya memihak pada mazhab, organisasi kemasyarakatan, partai politik, dan teologi tertentu. Fakta tersebut merupakan bagian dari gambaran diskursus dan praksis anti radikalisme di PPMI Assalaam. ${ }^{35}$

\section{Pola dan Faktor-faktor yang Mempengaruhi Pengembangan Resistensi atas Radikalisme di Pesantren}

Pola resistensi terahadap gerakan radikalisme muncul sebagai bagian dari reproduksi kebudayaan. Oleh Irwan Abdullah ${ }^{36}$ dijelaskan sebagai proses aktif yang menegaskan keberadaan dalam kehidupan sosial yang mengharuskan adanya adaptasi bagi kelompok yang mempunyai latar belakang berbeda. Resistensi merupakan bagian dari upaya reproduksi budaya tersebut. Resistensi merupakan reproduksi identitas kultural sekelompok orang di dalam konteks sosial budaya tertentu. Merebaknya gerakan radikalisme Islam yang selama ini mewacana berakar pada dunia pesantren merupakan konteks yang menimbulkan resistensi. Gambaran yang paling umum dan sederhana atas bentuk resistensi pesantren atas gerakan radikalisme adalah penolakan dan penentangan. Namun demikian dalam ranah praksis muncul beragam bentuk

\footnotetext{
${ }^{34}$ Keassalaaman, h. 24.

${ }^{35}$ Keassalaaman, h. 24.

${ }^{36}$ Dalam Kunthi Tridewiyanti, "Perempuan Arab Ba-Alawi dalam Sistem Perkawinan: Reproduksi Kebudayaan dan Resistensi”, Disertasi, (Jakarta: FISIP UI, 2009), h. 24.
} 
yang bersifat konsisten sehingga oleh peneliti dipahami sebagai pola. Keragaman bentuk yang konsisten tersebut dipengaruhi oleh beragam faktor.

Pondok Pesantren Al-Muayyad Surakarta juga menolak atau tidak setuju pada gerakan Islam radikal. Namun Al-Muayyad tidak menyalahkan pemahaman kelompok garis keras, karena itu pilihannya, respons Al-Muayyad terhadap kelompok Islam radikal bukan-lah sebagai reaksi, tetapi memandang Islam pada zaman sekarang sudah tidak sama dengan zamannya Shalahudin AlAyyubi yang meniscayakan penggunaan senjata. Atas dasar inilah, pengajaran kitab tafsir misalnya, ketika bersinggungan dengan ayat-ayat yang menjelaskan tentang perang, ustadz meluruskan pemahaman dengan tafsir yang inklusif. Demikian juga, penjelasan tafsir yang berhubungan dengan pemberitaan teroris melalui media. Ustadz mengingatkan santri agar jangan berperilaku seperti berita di TV, dan jangan menjadi "pengantin" pelaku pemboman. Perilaku tersebut, tidak lagi sesuai dengan makna dakwah pada zaman sekarang.

Inklusivitas doktrin yang ditanamkan bagi santri Al-Muayyad menurut peneliti dikarenakan pengaruh ajaran Ahlus Sunnah wal Jama'ah (ASWAJA) yang menjadi salah satu misi Pesantren Al-Muayyad. Ajaran ASWAJA mengandung berbagai macam prinsip, di antaranya adalah tasāmuḥ (toleransi), tawassut (pertengahan), dan tawāzun (keseimbangan). Nilai-nilai inilah yang secara tidak langsung mempengaruhi resistensi pesantren terhadap segala bentuk gerakan radikal.

Langkah pencegahan lain yang dilakukan Al-Muayyad adalah melalui pendidikan karakter, di antaranya melalui pembiasaan shalat berjama'ah, wiridan bersama, dan istighasah. Santri juga diberi nasihat agar berorganisasi yang baik, saling menyayangi dan membantu sesama teman. Melalui pembiasan semacam ini akan menanamkan sifat kasih sayang terhadap sesama manusia dalam diri santri.

Pendidikan karakter secara kultural juga dilakukan Al-Muayyad dengan memberikan kebebasan para pedagang jajanan berjualan di belakang pesantren. Tujuannya agar santri dapat membeli jajanan di luar pesantren. Nilai yang ingin ditanamkan oleh pesantren adalah agar santri bisa menghargai orang lain. Di samping itu, Al-Muayyad juga memberikan pendidikan anti radikal dengan mempopulerkan konsep musyawarah yang sangat dijunjung tinggi dalam Islam. Musyawarah itu mendidik menyelesaikan permasalahan dengan kepala dingin. Dengan pembiasaan musyawarah, santri akan mudah menerima perbedaan pendapat tanpa harus menggunakan kekerasan. 
Upaya kultural lainnya untuk membentengi santri agar tidak terjerumus dalam pemahaman yang radikal adalah melalui sinergi pola pendidikan di pesantren dan pendidikan di dalam keluarga. Al-Muayad menyadari bahwa pendidikan itu tidak 100 persen menjadi tanggung jawab pesantren. Pesantren hanya mempunyai tanggung jawab 25 persen, yang 75 persen itu menjadi tanggung jawab keluarga. Atas dasar filosofi inilah pada saat liburan santri AlMuayyad harus dijemput keluarga. Pada saat penjemputan ini, pengurus berdialog dengan wali santri. Di samping itu ada pertemuan khusus selapanan sekali antara pihak pesantren dengan wali santri.

Langkah lain yang dilakukan Al-Muayyad agar santri menjauhi paham dan perilaku radikal adalah melalui penerjunan santri ke masyarakat. Al-Muayyad memiliki program AMD (Achievement Motivation Development) yakni penerjunan santri ke masyarakat. Santri sejulah sekitar 100-an orang dikirim keluar kabupaten seperti Klaten dan Magelang. Mereka live in bersama-sama masyarakat selama 3 hari seperti mahasiswa sedang Kuliah Kerja Nyata dengan dibimbing oleh santri Al-Muayyad di Windan yang notabene-nya mahasiswa. Hal ini dilakukan secara rutin dan berkala bagi santri-santri kelas 2 SMA/Aliyah. Mereka dilatih memahami realitas masyarakat, belajar mengetahui apa yang dibutuhkan masyarakat, serta latihan melakukan pemberdayaan masyarakat sesuai usia mereka dari hal terkecil, misalnya mengajar TPQ. Melalui pembiasaan hidup secara nyata di tengah masyarakat, santri akan belajar memahami karakteristik suatu masyarakat dengan perbedaanperbedaan menjadi salah satu hal nyata dalam kehidupan masyarakat.

Penolakan Pesantren Al-Muayyad terhadap gerakan radikal juga dilatarbelakangi dampak negatif dari "cap Solo" sebagai "sarang teroris". Keluarga AlMuayyad pernah terkena dampak negatif secara langsung dari kondisi ini. Faishol menceritakan kasus kakaknya kira-kira 5 tahun-an lalu. Pada saat itu ada program ke Kairo dari Departemen Agama. Pada saat di Bandara ada pemerikasaan imigrasi diketahui KTP-nya dari Solo, kakaknya ditahan sampai setengah hari. Saat interview pertanyaan yang diajukan kepada kakaknya adalah berapa kilo meter dari pesantren yang menjadi pemasok teroris? Ketika dijawab jaraknya 2-3 kilo meter, akhirnya kakaknya ditahan di bandara sampai setengah hari. Kakaknya baru dilepaskan setelah menunjukkan fotonya bersama Gus Dur (mantan Presiden RI). 
Integrasi dalam kurikulum dan tata nilai tentang radikalisme dan anti radikalisme dikembangkan juga di Pondok Pesantren Modern Islam (PPMI) Assalaam. Islam dalam pandangan dan pemahaman PPMI Assalaam merupakan Islam moderat. Ia hadir di tengah-tengah, dalam suatu keseimbangan antara kanan ataupun kiri, antara atas ataupun bawah, antara depan atau belakang. Islam bagi PPMI Assalaam harus mampu melahirkan ummatan wasațan, suatu umat yang berada di tengah-tengah. Ummatan wasațan merupakan poros kebaikan dan kebajikan untuk semua umat manusia. Atas dasar prinsip ini, maka PPMI Assalaam bisa berkontribusi dalam mewujudkan kehidupan di dunia yang penuh dengan perdamaian melalui pendidikan dan pengajaran. ${ }^{37}$

Resistensi PPMI Assalaam terbangun dan mewujud dalam penerimaannya atas modernisasi secara penuh dan kreatif. Tidak semua kalangan Islam atau komunitas pesantren mau menerima modernitas sebagai realitas dalam kehidupan masyarakat, apalagi dalam pengelolaan pesantren. Banyak kalangan Muslim atau pesantren yang menolak modernitas. Mereka memusuhi dan berjuang untuk melawannya secara radikal. Modernitas dianggap sebagai faktor penyebab munculnya berbagai masalah sosial keislaman di masyarakat. Modernisasi merupakan biang dari degradasi moral keagamaan masyarakat. Materialisme, pragmatisme, individualisme, dan bahkan sekularisme merupakan penyakit masyarakat produk varian dari berkembangnya modernisasi. Radikalisme Islam di Indonesia di antara faktor yang menyebabkannya muncul yaitu faktor modernisasi.

Penerimaan PPMI Assalaam atas modernitas sangat jelas terlihat dalam kata modern yang melekat pada nama pondok pesantren. Modernisasi dimaknai secara berbeda oleh para pendiri PPMI Assalaam. Bagi pendiri PPMI Assalaam yaitu: KH. Djamaludin, H. Abdullah Marzuki, dan Hj. Siti Aminah Abdullah, kata modern yang melekat dalam nama PPMI Assalaam, mengandung beberapa makna sebagai berikut: ${ }^{38}$ (1) Memotivasi santri agar selalu mampu memberikan jawaban secara handal terhadap tantangan kehidupan yang sesuai dengan tuntutan perkembangan zaman. (2) Memadukan secara harmonis tradisi pesantren dengan sistem pendidikan persekolahan mutakhir.

\footnotetext{
${ }^{37}$ Keassalaaman, h. 21.

${ }^{38}$ Keassalaaman, h. 23
} 
(3) Mengubah citra negatif (kumuh dan gudikan) terhadap pondok pesantren. (4) Agar pondok pesantren menjadi lembaga yang memiliki kredibilitas dalam bidang pendidikan Islam.

Mengacu pada empat makna modernitas tersebut, maka pola kerja (manajemen) pondok tidak lagi berdasarkan tuntutan emansipatoris yang bersifat emosional dan sentimen keagamaan, tetapi harus berdasarkan logika kelembagaan agama yang sehat dan berorientasi ke masa depan. Hal ini merujuk pada al-Qur'an dengan istilah "wa'l-'āqibatu li 'l-muttaqīn", yang maknanya adalah bahwa nasib baik di masa yang akan datang hanyalah untuk orangorang yang taqwa. 39

Resistensi pesantren Assalaam terhadap radikalisme bisa ditemukan dalam prinsip dasar pengembangan kemampuan santri. Salah satunya prinsip tafaqquh fi 'l-din. Prinsip ini mengharuskan seorang santri memiliki kemampuan dalam mempelajari, memahami, dan menguasai ilmu-ilmu utama dalam Islam. Ilmu-ilmu utama tersebut meliputi; aqidah, syari'ah, akhlak, al-Qur'an, Hadits, dan Bahasa Arab dalam hidup dan kehidupannya. Prinsip ini akan menjadikan santri memiliki penghayatan yang benar dan kuat atas 'Aqīdah Islāmiyyah, sehingga memiliki dasar dalam memilah dan memilih sikap dan tindakan dalam menghadapi realitas kehidupan. Peneguhan prinsip tafaqquh $f i$ I-din dalam bentuk menghindarkan santri dari sifat dan sikap mudah menyeleweng dari garis hidup yang Islami. Sifat dan sikap tersebut meliputi; sifat materialistik-sekularistik yang menghambakan diri pada materi dan kekuasaan keduniawian. ${ }^{40}$

Bentuk resistensi terhadap radikalisme yang lain, yaitu pengembangan akhlak (suluk) santri. Suluk diwujudkan dalam hubungan santri dengan siapa pun, terutama pada Sang Khaliq. Landasan dalam penerapan suluk santri adalah al-Qur'an, al-Sunnah, dan 'urf masyarakat yang sesuai dengan Islam. Suluk santri selain kepada Allah SWT., juga pada Rasul-Nya, terhadap al-Qur'an, orang tua, diri sendiri, adab terhadap ustadz dan karyawan, teman, pergaulan dan bahkan adab berpakaian. ${ }^{41}$

\footnotetext{
${ }^{39}$ Keassalaaman, h. 23-24.

${ }^{40}$ Keassalaaman, h. 27.

${ }^{41}$ Keassalaaman, h. 62-66.
} 


\section{E. Kesimpulan}

Dialektika radikalisme dan antiradikalisme dalam kehidupan pesantren bergerak pada aras wacana dan praksis. Keduanya saling terkait sebagai realitas yang seringkali kontradiktif dan saling memperkuat. Wacana radikalisme dipahami masyarakat pesantren sebagai seuatu diantara realitas nyata dan tidak nyata. Sebagai realitas tidak nyata radikalisme merupakan sesuatu yang dominan karena menjadi komoditas pemberitaan media massa, sehingga sangat jauh dari kehidupan pesantren. Sebagai suatu kenyataan radikalisme merupakan suatu bentuk tindakan dan gerakan yang harus dicegah, ditolak, dan dilawan. Sifatnya yang destruktif, akan berimplikasi pada kehidupan beragama yang jauh dari tujuan keislaman sebagai raḥmatan li 'l'ālamin. Juga akan meruntuhkan keyakinan dan kepercayaan masyarakat akan agama Islam.

Cara pandang radikalisme yang sempit dalam memahami persoalan kehidupan sosial keagamaan, akan berakibat pada muncul tindakan kekerasan dalam berbagai bentuk di masyarakat. Oleh karenannya pesantren mengembangkan pola melawan radikalisme dalam bentuk anti radikalisme. Fakta yang ada seringkali gerakan anti radikalisme di pesantren bersifat reaktif, sehingga anti radikalisme merupakan bentuk lain dari resistensi masyarakat pesantren. Gerakan anti radikalisme di pesantren bermuara pada dua bentuk kontra radikalisme dan deradiklisme. Dalam praksisnya dilakukan dengan pendekatan kultural melalui caracter building dengan pengenalan hidup bermasyarakat secara lebih mendalam. Juga menggunakan pendekatan formal dengan mengintegrasikan dalam sistem pembelajaran, relasi sosial kelembagaan dan tata kelola pesantren.

Spirit anti radikalisme tidak bisa lepas dari nilai-nilai dasar yang menjadi keyakinan pesantren, misalnya; ajaran Aswaja (Ahl al-Sunnah wa 'I-Jamā'ah) yang mengajarkan prinsip tasāmuḥ (toleransi), tawassuṭ (sederhana), tawāzun (keseimbangan). Spirit modernitas yang diejawantahkan dalam manajemen pesantren yang didasarkan pada logika kelembagaan agama yang sehat dan berorientasi ke masa depan. Juga penguatan ideologi, politik, organisasi, dan sosial-budaya, insan yang selalu menebar kedamaian sesuai prinsip Islam raḥmatan li' l-'àlamin. [w] 


\section{BIBLIOGRAFI}

Abercrombie, Nicholas, dkk., Kamus Sosiologi, Yogyakarta: Pustaka Pelajar, 2010.

Appleby, R. Scott, "The Ambivalence of the Sacred Religion, Violence, and Reconciliation, dalam Badrus Sholeh, dkk, "Agama, Etnisitas dan Radikalisme: Pluralitas Masyarakat Kota Solo", laporan penelitian, UIN Syarif Hidayatullah Jakarta.

Azis, Abdul dkk, (ed.), Gerakan Islam Kontemporer di Indonesia, Jakarta: Diva Pustaka, 2006.

Berger, Peter L., Langit Suci, Agama Sebagai Realitas Sosial, terj. Hartono. Jakarta: LP3ES, 1991.

Berger, Peter L., dan Thomas Luckmann, Tafsir Sosial Atas Kenyataan, terj. Hasan Basari, Jakarta: LP3ES, 1990.

Darmadji, Ahmad, "Pondok Pesantren dan Deradikalisasi Islam di Indonesia", Jurnal Millah, Vol. XI, No 1, Agustus 2011.

Giddens, Anthony, Problematika Utama dalam Teori Sosial: Aksi, Struktur, dan Kontradiksi dalam Analisis Sosial, terj. Daryatno, Yogyakarta: Pustaka Pelajar, 2009.

Hamilton, Peter, (ed.), Talcot Parsons dan Pemikirannya, terj. Hartono Hadikusumo, Yogyakarta: Tiara Wacana, 1990.

Ife, Jim dan Frank Tesoriero, Community Development; Alternatif Pengembangan Masyarakat di Era Globalisasi, terj. Sastrawan Manulang dkk.; Yogyakarta: Pustaka Pelajar, 2008.

Jary, David \& Julia Jary, Dictionary of Sociology. Glasgow: Harper Collins Publisher, 1991.

Jinan, Muthoharun, "Melacak Akar Ideologi Puritanisme Islam: Survei Biografi atas "Tiga Abdullah", Walisongo - Jurnal Penelitian Sosial Keagamaan, Vol. 22, No. 2, November 2014.

Kosim, Mohammad, "Pesantren dan Wacana Radikalisme”, Jurnal Karsa, Vol. IX No. 1, April 2006. 
Lauer, Robert H, Perspektif tentang Perubahan Sosial, ed. II, terj. Alimandan. Jakarta: Bina Aksara, 1989.

Machali, Imam, "Peace Education dan Deradikalisasi Agama”, Jurnal Pendidikan Islam, Vol. II, No. 1, Juni 2013/1434 H.

Mulkhan, Abdul Munir dan Bilveer Singh, Demokrasi di bawah Bayangan Mimpi N-11; Dilema Poltik Islam dalam Peradaban Modern, Jakarta: Penerbit Buku Kompas, 2011.

Nottingham, Elizabeth K., Agama dan Masyarakat, edisi terjemahan, Jakarta: Rajawali Pers, 1997.

Nuhrison M. Nuh, (ed.), Peranan Pesantren dalam mengembangkan Budaya Damai, Jakarta: Badan Litbang dan Diklat Kementerian Agama, 2010.

Qodir, Zuly, Islam Liberal Paradigma Baru Wacana dan Aksi Islam Indonesia. Yogyakarta: Pustaka Pelajar, 2007.

Raharjo, M. Dawam, "Fanatisme dan Toleransi", pengantar dalam Irwan Masduqi, Berislam Secara Toleran. Bandung: Mizan, 2011.

Ritzer, George, Teori Sosiologi, terj. Saud Pasaribu, Rh. Widodo, dan Eka Adhinugraha, Yogyakarta: Pustaka Pelajar, 2012.

Salenda, Kasjim, Terorisme dan Jihad dalam Perspektif Hukum Islam, Jakarta: Publisher Badan Litbang dan Diklat, Departemen Agama RI, 2009.

Syamsul Arifin \& Hasnan Bachtiar, "Deradikalisasi Ideologi Gerakan Islam Transnasional Radikal", Jurnal Harmoni, Vol. 12, No. 3, SeptemberDesember 2013.

Tridewiyanti, Kunthi, "Perempuan Arab Ba-Alawi dalam Sistem Perkawinan: Reproduksi Kebudayaan dan Resistensi", Disertasi, FISIP UI, Jakarta, 2009.

Turmudzi, Endang, dkk. (ed.), Islam dan Radikalisme di Indonesia, LIPI Press: Jakarta, 2005.

Turner, Bryan S., Relasi Agama dan Teori Sosial Kontemporer, terj. Inyiak Ridwan Muzir, Yogyakarta: IRCiSoD, 2012.

Wiktorowicz, Quintan, Gerakan Sosial Islam; Teori, Pendekatan dan Studi Kasus, Jakarta: Gading Publishing, 2012.

\section{Internet:}

http://assalaam.or.id/id/sample-page/visi-misi/, diakses pada tanggal 5 November 2014.

Walisongo, Volume 23, Nomor 1, Mei 2015 
http://harian-oftheday.blogspot.com/2011/09/ponpes-of-day-pondokpesantren-al.html, diakses pada tanggal 2 Oktober 2014.

http://www.amwiner.org/pondok-pesantren-al-muayyad-windan/, diakses pada tanggal 2 Oktober 2014.

\section{Wawancara:}

Faishol Rozaq, Ketua Umum Pesantren Al-Muayyad, Senin, 20 Oktober 2014, jam 09.00-11.30.

Komarudin, Kepala Humas PPMI Assalaam, Minggu, 16 November 2014, jam 10.00 . 